\title{
ANALISIS KETERAMPILAN GEOMETRI SISWA DALAM MENYELESAIKAN MASALAH TRANSFORMASI DAN KESEBANGUNAN GEOMETRI RUMAH ADAT OSING
}

\author{
Adinda Beauty Afnenda ${ }^{1}$, Titik Sugiarti ${ }^{2}$, Reza Ambarwati ${ }^{2}$, Sunardi ${ }^{2}$, Toto' Bara \\ Setiawan $^{2}$ \\ Program Studi Pendidikan Matematika, FKIP, Universitas Jember \\ Jalan Kalimantan 37 Kampus Tegalboto, Jember 68121 \\ E-mail: adindabeauty99@gmail.com
}

\begin{abstract}
This research aims to determine the geometry ability of class XI students in solving transformation problems and geometric similarities of the traditional Osing house. The subjects of this study were 6 students of class XI MIPA 4 SMAN 1 Tegaldlimo. Students are given questions of geometric transformation skills and geometric similarities tests, followed by interviews. This type of research is a qualitative descriptive study. The results obtained in the transformation of skills are students with high math scores first have all skills, students with low math scores first have all skills except applied skills, students with medium mathematics scores first only have drawing skills and applied skills, and students with moderate math scores second and second low math score students only have drawing skills only. As for similarity skills, almost all students have all skills. The second moderate math score students and first low math students had all skills except, applied skills.
\end{abstract}

Keyword: Geometry Skills, Transformation, Congruence, Osing House

\section{PENDAHULUAN}

Cabang ilmu matematika yang memiliki bentuk konkret di sekitar siswa adalah geometri. "Dari sudut pandang psikologi, geometri merupakan penyajian abstraksi dari pengalaman visual dan spasial, misalnya bidang, pola, pengukuran dan pemetaan. Bahkan, dari sudut pandang matematik, geometri menyediakan pendekatan-pendekatan untuk pemecahan masalah, misalnya gambar-gambar, diagram, sistem koordinat, vektor, dan transformasi" [1]. Dibutuhkan konsep matematis yang matang dalam menerapkan keterampilan geometri di setiap pembelajaran geometri terutama dalam menghadapi permasalahan geometri di kehidupan sehari-hari. Hal ini didukung adanya penerapan scientific approach pada pembelajaran matematika yang nantinya diharapkan cakap dalam pengetahuan, keterampilan dan sikap yang dapat digunakan dalam kehidupan bermasyarakat.

Matematika memiliki kaitan yang sangat erat dengan budaya (seni) dalam kehidupan masyarakat. Budaya adalah suatu cara atau pola atau pandangan hidup yang berkembang di tengah-tengah kelompok yang diwarisi dan mewarisi dari satu generasi ke generasi selanjutnya. Budaya memiliki pengaruh yang signifikan terhadap munculnya gagasan baru dalam peradaban yang dimana gagasan tersebut salah satu bentuk penyempurnaan hasil pemikiran yang sudah lama ada [2]. Keterkaitan antar keduanya ini dinamakan dengan etnomatematika. Etnomatematika melukiskan suatu upaya budaya tertentu yang dilakukan oleh sekelompok masyarakat dalam menjalani suatu aktivitas matematika. Seperti, mengelompokkan, menghitung, mengukur, menganalisis, dan

\footnotetext{
${ }^{1}$ Mahasiswa S1 Prodi Pendidikan Matematika FKIP Universitas Jember

${ }^{2}$ Dosen Prodi Pendidikan Matematika FKIP Universitas Jember
} 
membuat pola. Etnomatematika pada bangunan sering dijumpai. Rumah adat merupakan bangunan tempat tinggal yang berciri khusus yang menggambarkan masing-masing daerah.

Karakteristik etnomatematika pada rumah adat terdapat pada bagian-bagian dari rumah adat osing, model rumah maupun pemakaian ornamen atau motif yang digunakan. Bentuk atap rumah adat Osing menyerupai bangun prisma segitiga tanpa bidang tegak yang terdiri empat sisi miring yang berbentuk persegi panjang dengan ukuran panjang dan lebar yang senilai dengan ukuran panjang dan lebar atap rumah adat Osing lainnya, hal ini dapat dikatakan bahwa kerangka atap rumah adat Osing sebangun.
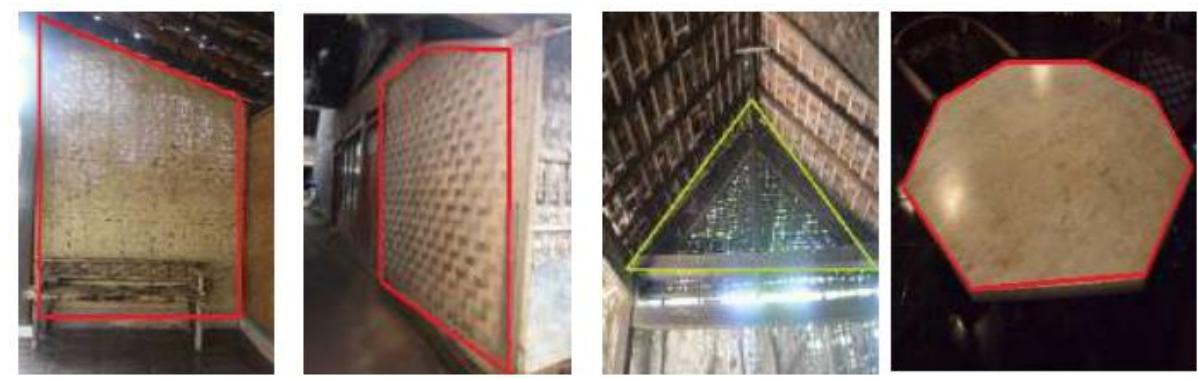

Gambar 1. Penerapan Bentuk Bangun Datar Pada Komponen Rumah Adat Osing
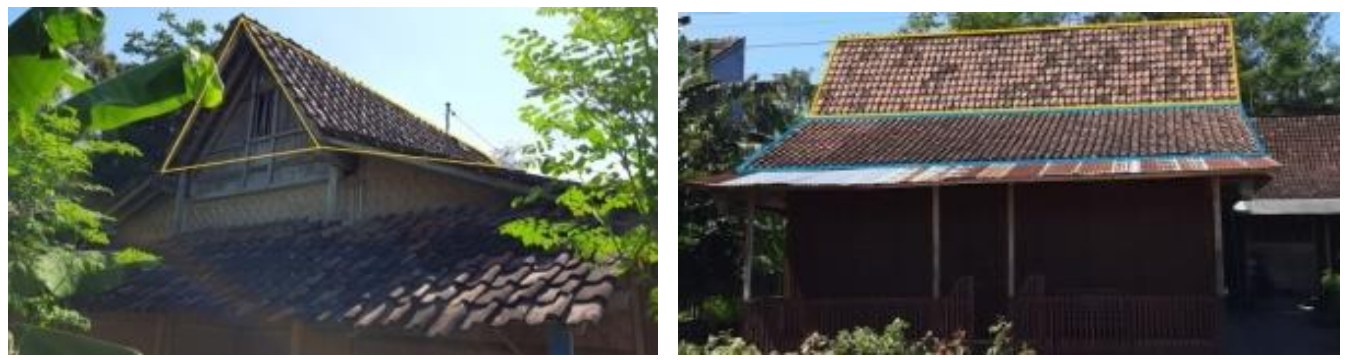

Gambar 2. Bentuk Atap yang Menyerupai Bentuk Geometri

Pada geometri sekolah terdapat pokok bahasan bentuk geometri, transformasi geometri, dan kesebangunan geometri. Bangun datar adalah bangun dua dimensi atau bidang datar [3]. Misalnya segitiga, segiempat, dan seterusnya hingga segi banyak. Transformasi geometri merupakan pemindahan objek geometri (titik, garis, dan bidang datar) pada bidang [4]. Seperti translasi, refleksi, dilatasi, dan rotasi. Dua bangun geometri memiliki bentuk yang sama maka dua bangun tersebut dikatakan sebangun [5]. Fokus penelitian ini adalah masalah transformasi geometri dan kesebangunan pada segiempat komponen rumah adat Osing.

National Council of Teachers of Mathematics telah menggarisbawahi bahwa keterampilan siswa menengah atas haruslah mulai dituntun untuk dapat mengerahkan pengetahuannya mengenai klasifikasi bangun datar secara lebih terstruktur [6]. Itulah mengapa pentingnya keterampilan geometri dibangun. Hoffer mengungkapkan bahwa lima keterampilan dasar dalam belajar geometri yakni, keterampilan visual, keterampilan verbal, keterampilan menggambar, keterampilan logika, dan keterampilan terapan [7].

Menurut National Council of Teachers of Mathematics (NCTM) menyatakan kemampuan geometri yang harus dikuasai siswa secara umum adalah: 1) mampu menganalisis karakter dan sifat dari bentuk geometri baik 2D maupun 3D serta mampu membangun hubungan geometri yang terkait; 2) mampu menentukan kedudukan suatu titik secara spesifik dan gambaran hubungan spasial dengan sistem geometri lainnya; 3) aplikasi transformasi dan menggunakannya secara sistematis guna menganalisis konsep 
matematika geometri yang diterapkan; 4) menggunakan visualisasi, penalaran spasial, dan model geometri untuk menyelesaikan permasalahan [8]. Berdasarkan indikator keterampilan geometri dari Hoffer dan NCTM, di dapatkan dua buah indikator baru dengan mengadaptasi indikator tersebut adalah indikator keterampilan geometri pada transformasi geometri materi segiempat dan indikator keterampilan geometri pada kesebangunan materi segiempat.

Dengan melihat fakta-fakta tersebut, perlu adanya analisis keterampilan geometri siswa secara mendetail dalam menyelesaikan masalah geometri yang berorientasi pada permasalahan budaya agar guru dapat mengetahui keterampilan geometri siswa dan menjadikan belajar lebih efektif dalam memecahkan masalah matematika.

\section{METODE PENELITIAN}

Penelitian ini merupakan penelitian deskriptif kualitatif. Penelitian ini dilakukan pada kelas XI MIPA 4 SMAN 1 Tegaldlimo dengan pemilihan subjek penelitian yang didasarkan pada data nilai matematika terakhir siswa dan informasi dari guru matematika. Pemilihan kelas XI MIPA 4 ini dilakukan karena kelas tersebut tergolong kelas yang kondusif dan memiliki tingkatan nilai siswa yang beragam. Subjek penelitian berjumlah enam siswa yang terdiri dari dua siswa dengan nilai matematika tinggi, dua siswa dengan nilai matematika sedang, dan dua siswa dengan nilai matematika rendah.

Metode pengumpulan data yang dilakukan dengan memberikan soal tes dan wawancara. Terdapat dua macam soal tes yaitu soal tes keterampilan transformasi geometri dan keterampilan kesebangunan geometri yang bertujuan untuk mengetahui tingkat keterampilan geometri siswa. Kemudian dilanjutkan dengan wawancara subjek penelitian guna mendalami hasil tes siswa.

Instrumen penelitian yang digunakan harus melalui proses validasi oleh validator. Validasi instrumen dilakukan oleh dua dosen Program Studi Pendidikan Matematika Fakultas Keguruan dan Ilmu Pendidikan Universitas Jember dan satu guru matematika SMAN 1 Tegaldlimo. Tingkat kevalidan instrumen menjadi penentu kelayakan suatu instrumen yang digunakan dalam penelitian. Instrumen penelitian yang dapat digunakan adalah instrumen penelitian yang valid dengan nilai $2,5 \leq V a \leq 3$.

\section{HASIL DAN PEMBAHASAN}

Hasil validasi instrumen soal tes keterampilan geometri dan pedoman wawancara berturut-turut 2,8 dan 2,8 yang artinya instrumen tersebut valid dan dapat digunakan dalam penelitian. Dengan pemilihan subjek penelitian yang didasarkan pada data nilai matematika terakhir siswa dan informasi dari guru matematika di dapatkan enam siswa yang disajikan pada Tabel 3 berikut.

Tabel 1. Subjek Penelitian

\begin{tabular}{lcc}
\hline \multicolumn{1}{c}{ Nama } & Kode Siswa & Nilai Matematika \\
\hline R. I. S. S. & ST1 & Tinggi \\
\hline O. S. W. & ST2 & Tinggi \\
\hline S. W. P. S. & SS1 & Sedang \\
\hline N. A. & SS2 & Sedang \\
\hline S. A. Z. & SR1 & Rendah \\
\hline T. A. A. P & SR2 & Rendah \\
\hline
\end{tabular}

Analisis data pada penelitian ini diperoleh dari hasil tes keterampilan transformasi geometri, tes kesebangunan geometri, dan wawancara dengan subjek penelitian. Hasil wawancara tersebut guna memperjelas dan mendukung hasil tes yang didapat subjek 
penelitian. Ketercapaian siswa terhadap indikator keterampilan transformasi geometri dan kesebangunan dapat dilihat pada Tabel 2 dan Tabel 5.

Tabel 2. Pencapaian Indikator Keterampilan Transformasi Geometri

\begin{tabular}{|c|c|c|c|c|c|c|c|}
\hline $\begin{array}{c}\text { Keterampilan } \\
\text { Geometri }\end{array}$ & Indikator & $\begin{array}{c}\text { ST } \\
1\end{array}$ & $\begin{array}{c}\text { ST } \\
2\end{array}$ & $\begin{array}{c}\text { SS } \\
1\end{array}$ & $\begin{array}{c}\text { SS } \\
2\end{array}$ & $\begin{array}{c}\text { SR } \\
1\end{array}$ & $\begin{array}{c}\text { SR } \\
2 \\
\end{array}$ \\
\hline \multirow{2}{*}{$\begin{array}{l}\text { Keterampilan } \\
\text { Visual } \\
\text { (minimal } 2 \\
\text { indikator) }\end{array}$} & $\begin{array}{l}\text { Menyebutkan berbagai bentuk } \\
\text { transformasi geometri } \\
\text { segiempat berdasarkan gambar } \\
\text { yang diberikan. }\end{array}$ & $\checkmark$ & $\checkmark$ & - & - & $\checkmark$ & - \\
\hline & $\begin{array}{l}\text { Menyebutkan sifat-sifat dari } \\
\text { segiempat berdasarkan konsep } \\
\text { transformasi geometri pada } \\
\text { objek visual. }\end{array}$ & $\checkmark$ & $\checkmark$ & $\checkmark$ & $\checkmark$ & $\checkmark$ & $\checkmark$ \\
\hline \multirow{2}{*}{$\begin{array}{l}\text { Keterampilan } \\
\text { Verbal } \\
\text { (minimal } 2 \\
\text { indikator) }\end{array}$} & $\begin{array}{l}\text { Menyebutkan jenis transformasi } \\
\text { geometri berdasarkan gambar } \\
\text { segiempat yang diberikan. }\end{array}$ & $\checkmark$ & $\checkmark$ & - & - & $\checkmark$ & - \\
\hline & $\begin{array}{l}\text { Menerangkan transformasi } \\
\text { geometri yang dikenai antar } \\
\text { bangun segiempat. }\end{array}$ & $\checkmark$ & $\checkmark$ & - & - & $\checkmark$ & - \\
\hline \multirow{2}{*}{$\begin{array}{l}\text { Keterampilan } \\
\text { Menggambar } \\
\text { (minimal } 2 \\
\text { indikator) }\end{array}$} & $\begin{array}{l}\text { Menggambar segiempat yang } \\
\text { dikenai transformasi geometri } \\
\text { dan melabeli bangun. }\end{array}$ & $\checkmark$ & $\checkmark$ & $\checkmark$ & $\checkmark$ & $\checkmark$ & $\checkmark$ \\
\hline & $\begin{array}{l}\text { Menyebutkan akibat dari } \\
\text { sebuah bangun yang dikenai } \\
\text { konsep transformasi geometri. }\end{array}$ & $\checkmark$ & $\checkmark$ & $\checkmark$ & $\checkmark$ & $\checkmark$ & $\checkmark$ \\
\hline \multirow{2}{*}{$\begin{array}{l}\text { Keterampilan } \\
\text { Terapan } \\
\text { (minimal } 2 \\
\text { indikator) }\end{array}$} & $\begin{array}{l}\text { Mengidentifikasi transformasi } \\
\text { geometri segiempat } \\
\text { berdasarkan objek fisiknya. }\end{array}$ & $\checkmark$ & $\checkmark$ & $\checkmark$ & $\checkmark$ & - & - \\
\hline & $\begin{array}{l}\text { Mengembangkan model } \\
\text { matematis segiempat melalui } \\
\text { konsep transformasi geometri. }\end{array}$ & $\checkmark$ & - & $\checkmark$ & - & - & - \\
\hline \multicolumn{2}{|c|}{ Jumlah indikator yang dicapai } & 8 & 7 & 5 & 4 & 6 & 3 \\
\hline \multicolumn{2}{|c|}{ Jumlah keterampilan yang dicapai } & 4 & 3 & 2 & 1 & 3 & 1 \\
\hline
\end{tabular}

Tabel 3. Pencapaian Indikator Keterampilan Kesebangunan Geometri

\begin{tabular}{|c|c|c|c|c|c|c|c|}
\hline $\begin{array}{c}\text { Keterampilan } \\
\text { Geometri }\end{array}$ & Indikator & $\begin{array}{c}\text { ST } \\
1\end{array}$ & $\begin{array}{c}\text { ST } \\
2\end{array}$ & $\begin{array}{c}\text { SS } \\
1\end{array}$ & $\begin{array}{c}\text { SS } \\
2\end{array}$ & $\begin{array}{c}\text { SR } \\
1\end{array}$ & $\begin{array}{c}\text { SR } \\
2\end{array}$ \\
\hline \multirow{3}{*}{$\begin{array}{l}\text { Keterampilan } \\
\text { Visual } \\
\text { (minimal } 2 \\
\text { indikator) }\end{array}$} & $\begin{array}{l}\text { Menyebutkan segiempat } \\
\text { berdasarkan gambar } \\
\text { kesebangunan yang diberikan. }\end{array}$ & $\checkmark$ & $\checkmark$ & $\checkmark$ & $\checkmark$ & $\checkmark$ & $\checkmark$ \\
\hline & $\begin{array}{l}\text { Menyebutkan sifat-sifat dari } \\
\text { segiempat berdasarkan objek } \\
\text { visual yang menerapkan konsep } \\
\text { kesebangunan. }\end{array}$ & $\checkmark$ & $\checkmark$ & $\checkmark$ & $\checkmark$ & $\checkmark$ & $\checkmark$ \\
\hline & $\begin{array}{l}\text { Menyatakan hubungan } \\
\text { kesebangunan antar komponen } \\
\text { bangun segiempat. }\end{array}$ & $\checkmark$ & $\checkmark$ & $\checkmark$ & $\checkmark$ & $\checkmark$ & $\checkmark$ \\
\hline $\begin{array}{c}\text { Keterampilan } \\
\text { Verbal }\end{array}$ & $\begin{array}{l}\text { Menyebutkan nama segiempat } \\
\text { berdasarkan gambar } \\
\text { kesebangunan yang diberikan. }\end{array}$ & $\checkmark$ & $\checkmark$ & $\checkmark$ & $\checkmark$ & $\checkmark$ & $\checkmark$ \\
\hline
\end{tabular}




\begin{tabular}{|c|c|c|c|c|c|c|c|}
\hline $\begin{array}{c}\text { Keterampilan } \\
\text { Geometri }\end{array}$ & Indikator & $\begin{array}{c}\text { ST } \\
1\end{array}$ & $\begin{array}{c}\text { ST } \\
2\end{array}$ & $\begin{array}{c}\text { SS } \\
1 \\
\end{array}$ & $\begin{array}{c}\text { SS } \\
2\end{array}$ & $\begin{array}{c}\text { SR } \\
1 \\
\end{array}$ & $\begin{array}{c}\text { SR } \\
2 \\
\end{array}$ \\
\hline \multirow{3}{*}{$\begin{array}{l}\text { Keterampilan } \\
\text { Visual } \\
\text { (minimal } 2 \\
\text { indikator) }\end{array}$} & $\begin{array}{l}\text { Menyebutkan segiempat } \\
\text { berdasarkan gambar } \\
\text { kesebangunan yang diberikan. }\end{array}$ & $\checkmark$ & $\checkmark$ & $\checkmark$ & $\checkmark$ & $\checkmark$ & $\checkmark$ \\
\hline & $\begin{array}{l}\text { Menyebutkan sifat-sifat dari } \\
\text { segiempat berdasarkan objek } \\
\text { visual yang menerapkan konsep } \\
\text { kesebangunan. }\end{array}$ & $\checkmark$ & $\checkmark$ & $\checkmark$ & $\checkmark$ & $\checkmark$ & $\checkmark$ \\
\hline & $\begin{array}{l}\text { Menyatakan hubungan } \\
\text { kesebangunan antar komponen } \\
\text { bangun segiempat. }\end{array}$ & $\checkmark$ & $\checkmark$ & $\checkmark$ & $\checkmark$ & $\checkmark$ & $\checkmark$ \\
\hline $\begin{array}{l}\text { (minimal } 2 \\
\text { indikator) }\end{array}$ & $\begin{array}{l}\text { Merumuskan definisi segiempat } \\
\text { berdasarkan kesebangunan } \\
\text { segiempat. }\end{array}$ & $\checkmark$ & $\checkmark$ & $\checkmark$ & $\checkmark$ & $\checkmark$ & $\checkmark$ \\
\hline \multirow{2}{*}{$\begin{array}{l}\text { Keterampilan } \\
\text { Menggambar } \\
\text { (minimal } 2 \\
\text { indikator) }\end{array}$} & $\begin{array}{l}\text { Mengkonstruk segiempat } \\
\text { berdasarkan pernyataan } \\
\text { kesebangunan yang diberikan. }\end{array}$ & $\checkmark$ & $\checkmark$ & $\checkmark$ & $\checkmark$ & $\checkmark$ & $\checkmark$ \\
\hline & $\begin{array}{l}\text { Menyebutkan perbedaan dan } \\
\text { persamaan kesebangunan } \\
\text { segiempat. }\end{array}$ & $\checkmark$ & $\checkmark$ & $\checkmark$ & $\checkmark$ & $\checkmark$ & $\checkmark$ \\
\hline \multirow{2}{*}{$\begin{array}{l}\text { Keterampilan } \\
\text { Terapan } \\
\text { (minimal } 2 \\
\text { indikator) }\end{array}$} & $\begin{array}{l}\text { Membuat sketsa model } \\
\text { kesebangunan segiempat. }\end{array}$ & $\checkmark$ & $\checkmark$ & $\checkmark$ & - & - & $\checkmark$ \\
\hline & $\begin{array}{l}\text { Mengembangkan model } \\
\text { matematis segiempat melalui } \\
\text { konsep kesebangunan. }\end{array}$ & $\checkmark$ & $\checkmark$ & $\checkmark$ & - & - & $\checkmark$ \\
\hline \multicolumn{2}{|c|}{ Jumlah indikator yang dicapai } & 8 & 8 & 8 & 6 & 6 & 8 \\
\hline \multicolumn{2}{|c|}{ Jumlah keterampilan yang dipenuhi } & 4 & 4 & 4 & 3 & 3 & 4 \\
\hline
\end{tabular}

Berikut ini dibahas mengenai keterampilan geometri ST1 pada materi transformasi geometri. ST1 merupakan siswa dengan nilai matematika tinggi pertama, subjek mampu memenuhi semua indikator keterampilan visual, keterampilan verbal, keterampilan menggambar, dan keterampilan terapan. Hal tersebut dapat dilihat pada Tabel 4, terlihat bahwa ST1 mampu memenuhi indikator keterampilan visual dan verbal dimana mampu menjelaskan konsep transformasi pada dinding rumah adat Osing. Pada transkrip wawancara diketahui pula ST1 mampu memenuhi indikator kedua dari keterampilan visual yaitu menyebutkan sifat-sifat dari segiempat berdasarkan konsep dilatasi dan translasi pada objek visual yaitu dinding rumah adat Osing. ST1 juga memperkuat indikator tersebut pada transkrip wawancara bahwa terdapat satu sifat lagi yang dia ketahui selain dari yang dituliskan. ST1 juga memenuhi semua indikator keterampilan menggambar dan keterampilan terapan yang menunjukkan bahwa ST1 mampu menggambarkan segiempat berbentuk sebuah pintu Osing yang dikenai konsep refleksi dan mampu melabeli bangun segiempat dengan benar, dan mampu mengembangkan model matematis segiempat pada pagar rumah adat Osing yang berkonsep translasi.

Berikut ini membahas mengenai keterampilan geometri ST2 pada materi transformasi geometri, ST2 merupakan siswa dengan nilai matematika tinggi kedua. ST2 mampu memenuhi indikator keterampilan visual, keterampilan verbal, dan keterampilan menggambar, serta tidak mampu memenuhi indikator keterampilan terapan. Hal tersebut dapat dilihat pada Tabel 4. Berdasarkan hasil tes dan diperkuat dalam wawancara, diketahui bahwa ST2 mampu menyebutkan berbagai bentuk transformasi geometri 
segiempat berdasarkan gambar dinding rumah adat Osing, mampu menyebutkan sifatsifat dari segiempat berdasarkan gambar dinding rumah adat Osing yang berkonsep translasi dan dilatasi, mampu menerangkan konsep refleksi yang dikenai antar bangun segiempat, mampu menggambar segiempat yang dikenai refleksi dan melabeli bangun, dan mampu menyebutkan akibat dari sebuah bangun yang dikenai konsep refleksi.

Berikut ini membahas mengenai keterampilan geometri SS1 pada materi transformasi geometri, SS1 mampu memenuhi indikator keterampilan menggambar, dan keterampilan terapan. Hal tersebut dapat dilihat pada Tabel 4. SS1 merupakan siswa dengan nilai matematika sedang pertama. Berdasarkan hasil tes dan wawancara, terlihat bahwa SS1 mampu menggambar segiempat yang dikenai transformasi geometri dan melabeli bangun, dan mampu menyebutkan akibat dari sebuah bangun yang dikenai konsep refleksi. SS1 juga mampu menyebutkan akibat dari sebuah bangun yang dikenai refleksi itu menyerupai sebuah pintu rumah adat Osing dan mampu mengidentifikasi transformasi geometri segiempat berdasarkan gambar pagar rumah adat Osing yang ditampilkan, serta mampu mengembangkan model matematis segiempat pada pagar rumah adat Osing melalui konsep translasi.

Berikut ini membahas mengenai keterampilan geometri SS2 pada materi transformasi geometri, SS2 hanya mampu memenuhi satu keterampilan saja yaitu keterampilan menggambar, hal tersebut dapat dilihat pada Tabel 4. SS2 merupakan siswa dengan nilai matematika sedang kedua. Berdasarkan hasil tes dan wawancara, terlihat bahwa SS2 mampu menggambar segiempat yang dikenai transformasi geometri tetapi kurang mampu melabeli segiempat pada hasil refleksi dengan tepat, SS2 juga mampu menyebutkan dan mampu menjelaskan konsep refleksi yang mengenai bangun tersebut dengan tepat sehingga menghasilkan suatu bentuk komponen rumah adat Osing.

Berikut ini membahas mengenai keterampilan geometri SR1 pada materi transformasi geometri secara umum. SR1 mampu memenuhi tiga keterampilan yaitu keterampilan visual, keterampilan verbal, dan keterampilan menggambar, hal tersebut dapat dilihat pada Tabel 4. SR1 merupakan siswa dengan nilai matematika rendah pertama. Berdasarkan hasil tes dan wawancara, terlihat bahwa SR1 mampu menyebutkan sifat-sifat dari segiempat berdasarkan objek visual tersebut, mampu menjelaskan konsep translasi dan dilatasi berdasarkan gambar yang diberikan dan menggambar segiempat yang dikenai transformasi geometri dan melabeli bangun, serta menyebutkan akibat dari sebuah bangun yang dikenai konsep transformasi geometri.

Berikut ini membahas mengenai keterampilan geometri SR2 pada materi transformasi geometri secara umum. SR2 hanya mampu memenuhi keterampilan menggambar saja, hal tersebut dapat dilihat pada Tabel 4. SR2 merupakan siswa dengan nilai matematika rendah kedua. Berdasarkan hasil tes dan wawancara, terlihat bahwa SR2 terlihat tidak mampu menyebutkan jenis transformasi pada soal yang mnejadi indikator acuan dalam keterampilan visual dan verbal ini. Hal ini disebabkan SR2 lupa dan terlihat bingung ketika diminta untuk menjelaskan soal tersebut. Oleh karena itu, SR2 dapat dikatakan tidak memiliki keterampilan visual dan keterampilan verbal dalam menyelesaikan masalah transformasi. SR2 mampu memenuhi kedua indikator keterampilan menggambar. Indikator tersebut adalah menggambar segiempat yang dikenai transformasi geometri dan melabeli bangun, dan menyebutkan akibat dari sebuah segiempat yang dikenai konsep refleksi. SR2 juga menambahkan keterangan pada pelabelan bangun segiempat tersebut guna mengetahui perbedaan antara persegi dan persegi panjang. SR2 tidak mampu memahami soal dengan baik dan tidak mengerti jenisjenis trasnformasi, hal tersebut yang membuat tidak tercapainya indikator pada keterampilan terapan. 
Berikut ini membahas mengenai keterampilan geometri pada materi kesebangunan secara umum. ST1, ST2, SS1, dan SR2 mampu memenuhi indikator keterampilan geometri yang sama yaitu keterampilan visual, keterampilan verbal, keterampilan menggambar, dan keterampilan terapan. Hal tersebut dapat dilihat pada Tabel 3. ST1 merupakan siswa dengan nilai matematika tinggi pertama. ST2 merupakan siswa dengan nilai matematika tinggi kedua. SS1 merupakan siswa dengan nilai matematika sedang pertama. SS1 merupakan siswa dengan nilai matematika sedang pertama. SR2 merupakan siswa dengan nilai matematika tinggi rendah kedua. Berdasarkan hasil tes dan wawancara, terlihat bahwa subjek-subjek tersebut mampu menyebutkan segiempat berdasarkan gambar kesebangunan yang diberikan, menyebutkan sifat-sifat dari segiempat berdasarkan objek visual yang menerapkan konsep kesebangunan, mengetahui hubungan kesebangunan antar komponen bangun segiempat, menyebutkan nama segiempat berdasarkan gambar kesebangunan yang diberikan, dan merumuskan definisi segiempat berdasarkan kesebangunan segiempat. Oleh sebab itu, dapat dikatakan bahwa subjek tersbebut mampu mencapai indikator keterampilan visual dan keterampilan verbal secara keseluruhan. Terdapat dua indikator pencapaian dalam keterampilan ini dan subjek mampu mnecapai indikator tersebut yaitu dengan mampu mengkonstruk kumpulan koordinat yang membentuk sebuah bangun segiempat berdasarkan pernyataan kesebangunan yang diberikan dan mampu menyebutkan perbedaan lainnya yang diketahuinya. ST1, ST2, SS1, dan SR2 juga mampu membuat sketsa model kesebangunan segiempat, dan mampu mengembangkan model matematis segiempat melalui konsep kesebangunan. Dalam pengidentifikasikan sketsa model kesebangunan, salah satu subjek penelitian mampu menunjukkan bukti logis berupa ukuran persegi panjang yang menjadi acuan pensketsaannya.

Berikut ini membahas mengenai keterampilan geometri SS2 dan SR1 pada materi kesebangunan secara umum. SS2 dan SR1 memiliki keterampilan yang sama pula dengan mampu memenuhi tiga keterampilan yaitu keterampilan visual, keterampilan verbal, dan keterampilan menggambar. Hal tersebut dapat dilihat pada Tabel 3. SS2 merupakan siswa dengan nilai matematika sedang kedua dan SR1 merupakan siswa dengan nilai matematika rendah pertama. Berdasarkan hasil tes dan wawancara, terlihat bahwa subjek ini mampu menyebutkan macam-macam segiempat beserta sifat-sifatnya, merumuskan definisi segiempat dengan tepat, dan mengetahui hubungan kesebangunan antar bangun segiempat. Oleh sebab itu, SS2 dan SR1 memiliki keterampilan visual dan keterampilan verbal. SS2 dan SR1 juga mampu mengkonstruk segiempat berdasarkan soal dan mampu menyebutkan perbedaan persamaan segiempat dengan benar dan rinci. Selain itu, subjek mampu melabelkan hasil konstruksi dengan tepat yaitu menggunakan aksen. Terdapat dua indikator yang menjadi acuan dalam keterampilan terapan, yang pertama adalah membuat sketsa model kesebangunan segiempat dan yang kedua adalah mengembangkan model matematis segiempat melalui konsep kesebangunan. SS2 terlihat kurang mampu menjawab dengan tepat pada lembar jawabannya, dan tidak mampu menjelaskan alasan atas jawaban yang dituliskan. Untuk itu dapat dikatakan bahwa, SS2 tidak memiliki keterampilan terapan. SR1 juga tidak memiliki keterampilan terapan, hal tersebut diketahui dari ketidakmampuannya dalam memahami soal. Dalam wawancara, SR1 juga menegaskan bahwa ia hanya mampu menuliskan hal yang diketahui saja.

Berdasarkan hasil analisis terhadap penyelesaian soal tes keterampilan geometri materi transformasi dan kesebangunan geometri oleh enam siswa kelas XI MIPA 4, kecenderungan keterampilan geometri yang dimiliki siswa berdasarkan nilai matematika disajikan pada Gambar 3 dan Gambar 4. Menurut Hoffer ketercapaian keterampilan 
geometri siswa dilihat dari pemenuhan paling sedikit 2 indikator dari masing-masing keterampilan [9].
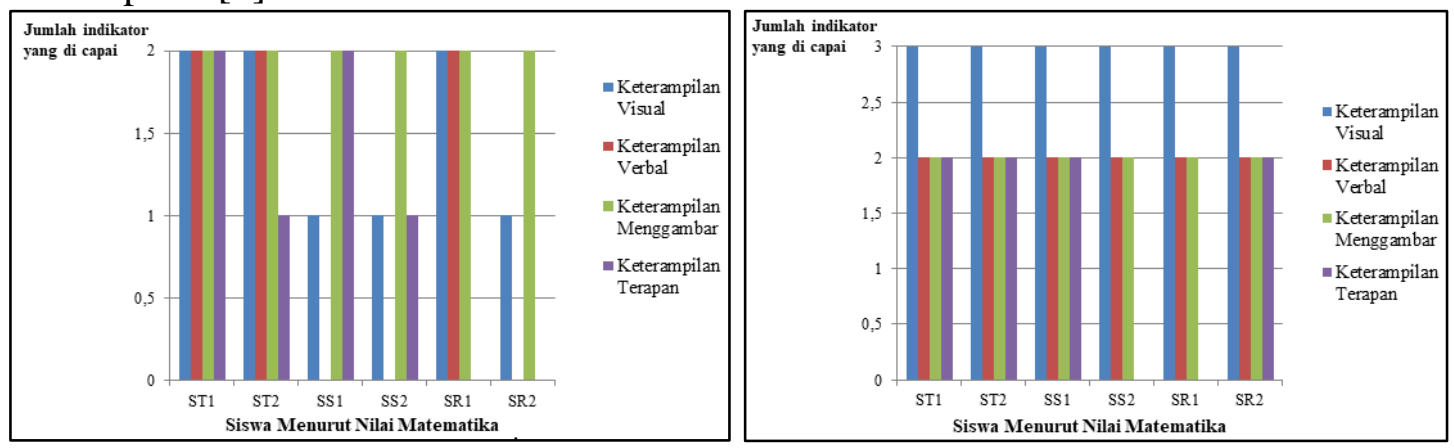

Gambar 3. Keterampilan Transformasi Geometri dan Kesebangunan Siswa Berdasarkan Nilai Matematika (dari kiri)

Berdasarkan Gambar 3, diketahui bahwa terdapat 2 indikator untuk setiap keterampilan. Siswa yang memiliki nilai matematika tinggi pertama memiliki keterampilan transformasi geometri yang sebanding dengan nilai matematikanya. Hal tersebut ditunjukkan dalam hasil analis jawaban siswa ini bahwa mampu memenuhi 2 indikator keterampilan visual, 2 indikator keterampilan verbal, 2 indikator keterampilan menggambar, dan 2 indikator keterampilan terapan. Berdasarkan peryataan Hoffer [9] mengenai ketercapaian keterampilan geometri dapat dikatakan bahwa siswa yang memiliki nilai matematika tinggi pertama memenuhi 8 indikator keterampilan geometri.

Siswa dengan nilai matematika tertinggi kedua mampu memenuhi 2 indikator keterampilan visual, 2 indikator keterampilan verbal, 2 indikator keterampilan menggambar, dan 1 indikator keterampilan terapan. Atas dasar hal tersebut, maka siswa nilai matematika tinggi kedua memiliki keterampilan visual, keterampilan verbal, dan keterampilan menggambar, serta tidak memiliki keterampilan terapan. Siswa nilai matematika tinggi kedua ini menjelaskan pada saat wawancara bahwa mengalami kebingungan dalam mengembangkan model matematis segiempat tersebut sehingga tidak mampu mencapai indikator keterampilan terapan. Hal tersebut menunjukkan bahwa ST2 belum memiliki keterampilan geometri yang bagus.

Siswa dengan nilai matematika sedang pertama yaitu siswa dengan kode SS1. Siswa ini mampu memenuhi 1 indikator keterampilan visual, 2 indikator keterampilan menggambar, dan 2 indikator keterampilan terapan. Oleh sebab itu, dapat dikatakan bahwa siswa nilai matematika sedang pertama memiliki keterampilan menggambar, dan keterampilan terapan tetapi tidak memiliki keterampilan visual dan keterampilan verbal. Hal tersebut terjadi lantaran siswa nilai sedang pertama ini tidak mampu menyebutkan jenis transformasi geometri segiempat pada gambar yang diberikan. Berdasarkan pernyataan ketercapaian keterampilan geometri Hoffer [9], dapat dikatakan bahwa siswa dengan nilai matematika sedang pertama memiliki keterampilan geometri yang rendah dikarenakan hanya mampu memenuhi 5 indikator.

Siswa dengan nilai matematika sedang kedua memiliki keterampilan yang berbeda jauh dengan siswa nilai matematika sedang pertama. Siswa ini hanya memiliki satu keterampilan yaitu keterampilan menggambar. Hal tersebut dikarenakan siswa nilai matematika sedang kedua mampu memenuhi 1 indikator keterampilan visual, 2 indikator keterampilan menggambar, dan 1 indikator keterampilan terapan. Oleh karena itu, siswa ini tidak memiliki keterampilan visual, keterampilan verbal, dan keterampilan terapan.

SR1 merupakan kode untuk siswa dengan nilai matematika rendah pertama. Siswa nilai matematika rendah pertama ini memiliki keterampilan transformasi geometri yang 
lebih banyak dibandingkan siswa keterampilan sedang pertama dan kedua. Siswa ini mampu memenuhi 2 indikator keterampilan visual, 2 indikator keterampilan verbal, dan 2 indikator keterampilan menggambar. Oleh karena itu, siswa ini memiliki keterampilan visual, keterampilan verbal, keterampilan menggambar tetapi tidak memiliki keterampilan terapan.

Siswa dengan nilai matematika rendah kedua ini memiliki keterampilan transformasi geometri yang sama dengan siswa nilai matematika sedang kedua atau siswa yang di beri kode SS2. Siswa ini mampu memenuhi 1 indikator keterampilan visual, dan 2 indikator keterampilan gambar. Oleh karena itu, siswa nilai matematika rendah ini memiliki keterampilan menggambar tetapi tidak memiliki keterampilan visual, keterampilan verbal, dan keterampilan terapan.

Dari keenam subjek penelitian tersebut, dapat disimpulkan bahwa hanya ada satu subjek yang memenuhi pernyataan ketercapaian keterampilan geometri Hoffer [9]. Berdasarkan hal tersebut dapat dikatakan bahwa keterampilan geometri dalam menyelesaikan setiap masalah transformasi geometri segiempat pada rumah adat Osing tergolong rendah.

Berikut ini membahas mengenai keterampilan geometri siswa berdasarkan nilai matematika dalam menyelesaikan masalah kesebangunan segiempat. Seperti yang telah dipaparkan analisis data menjelaskan bahwa siswa dengan kategori nilai yang berbeda tersebut memiliki keterampilan kesebangunan tergolong tinggi dan hampir seragam. Berdasarkan Gambar 3, diketahui bahwa terdapat 3 indikator untuk keterampilan visual dan 2 indikator untuk selain keterampilan visual. Siswa yang memiliki nilai matematika tinggi pertama atau siswa yang diberi kode ST1 memiliki keterampilan transformasi geometri yang sebanding dengan nilai matematikanya. Siswa dengan nilai matematika tinggi pertama memiliki keterampilan kesebangunan yang sama dengan siswa dengan nilai matematika kedua atau yang diberi kode ST2 dan siswa dengan matematika sedang pertama dengan kode SS1. Hal tersebut ditunjukkan dalam hasil analis jawaban siswa ini bahwa mampu memenuhi 3 indikator keterampilan visual, 2 indikator keterampilan verbal, 2 indikator keterampilan menggambar, dan 2 indikator keterampilan terapan. Berdasarkan pernyataan ketercapaian keterampilan geometri Hoffer [9], dapat dikatakan bahwa ST1, ST2, dan SS1 memiliki keterampilan geometri yang tinggi dikarenakan hanya mampu memenuhi 9 indikator. Untuk itu, dapat dikatakan bahwa siswa yang memiliki nilai matematika tinggi pertama mempunyai semua keterampilan geometri dalam menyelesaikan masalah transformasi geometri pada rumah adat Osing.

Siswa dengan nilai matematika sedang kedua memiliki keterampilan yang berbeda dengan siswa nilai matematika sedang pertama. Siswa ini hanya memiliki tiga keterampilan saja. Hal tersebut dikarenakan siswa nilai matematika sedang kedua mampu memenuhi 3 indikator keterampilan visual, 2 indikator keterampilan verbal, dan 2 indikator keterampilan menggambar. Oleh karena itu, siswa ini tidak memiliki keterampilan terapan tetapi memiliki keterampilan visual, keterampilan verbal, dan keterampilan menggambar.

SR1 merupakan kode untuk siswa dengan nilai matematika rendah pertama. Siswa nilai matematika rendah pertama ini memiliki keterampilan kesebangunan segiempat yang sama dengan siswa keterampilan sedang kedua. Siswa ini mampu memenuhi 3 indikator keterampilan visual, 2 indikator keterampilan verbal, dan 2 indikator keterampilan menggambar. Oleh karena itu, siswa ini memiliki keterampilan visual, keterampilan verbal, keterampilan menggambar, dan tidak memiliki keterampilan terapan. 
Siswa dengan nilai matematika rendah kedua ini memiliki keterampilan transformasi geometri yang sama dengan siswa nilai matematika tinggi pertama, siswa nilai matematika kedua, dan siswa nilai matematika sedang pertama. Siswa ini mampu memenuhi 3 indikator keterampilan visual, 2 indikator keterampilan verbal, 2 indikator keterampilan menggambar, dan 2 indikator keterampilan terapan. Berdasarkan pernyataan ketercapaian keterampilan geometri Hoffer [9], dapat dikatakan bahwa siswa ini memiliki keterampilan geometri yang tinggi pula dikarenakan mampu memenuhi lebih dari 8 indikator. Oleh karena itu, siswa nilai matematika rendah kedua ini memiliki semua keterampilan geometri dalam menyelesaikan kesebangunan geometri pada rumah adat Osing.

Dari keenam subjek penelitian tersebut, dapat disimpulkan bahwa hampir semua subjek memenuhi keempat keterampilan geometri dengan minimal 8 indikator yang didasarkan pada pernyataan ketercapaian keterampilan geometri Hoffer [9]. Untuk itu, dapat dikatakan bahwa keterampilan geometri dalam menyelesaikan masalah kesebangunan geometri segiempat pada rumah adat Osing tergolong tinggi.

\section{KESIMPULAN}

Berdasarkan hasil analisis dan pembahasan, dapat ditarik kesimpulan bahwa keterampilan geometri siswa kelas XI dalam menyelesaikan masalah transformasi geometri segiempat pada rumah adat Osing tergolong rendah, ditunjukkan dengan diperolehnya ketercapaian indikator keterampilan geometri. Dari 6 subjek, terdapat 5 subjek yang tidak memenuhi 8 indikator yaitu ST2, SS1, SS2, SR1, dan SR2. ST2 dan SR1 memenuhi indikator keterampilan visual, keterampilan verbal, dan keterampilan menggambar. Hal tesebut ditunjukkan dengan kemampuan subjek menyebutkan sifat dari segiempat berdasarkan konsep dilatasi dan translasi pada dinding rumah adat Osing, menerangkan jenis transformasi geometri pada dinding rumah adat Osing yang terdapat bangun segiempat, dan mampu menggambar segiempat berdasarkan rangkaian titik koordinat yang dikenai konsep refleksi dan melabeli bangun segiempat yang menyerupai sebuah pintu rumah adat Osing. SS1 memiliki dua keterampilan geometri yaitu keterampilan menggambar dan keterampilan terapan, hal tersebut ditunjukkan subjek mampu menggambar rangkaian titik koordinat yang dikenai konsep refleksi dan mampu menyebutkan akibat dari refleksi koordinat tersebut yaitu membentuk sebuah pintu rumah adat osing. Selain itu, SS1 mampu mengidentifikasi konsep translasi dan mengembangkan model matematis segiempat pada pagar rumah adat Osing. SS2 dan SR2 hanya memiliki keterampilan menggambar saja yang ditunjukkan dengan kemampuannya menggambar rangkaian titik koordinat yang dikenai konsep refleksi dan mampu menyebutkan akibat dari refleksi koordinat tersebut yaitu membentuk sebuah pintu rumah adat osing.

Keterampilan geometri siswa XI dalam menyelesaikan masalah kesebangunan segiempat pada rumah adat Osing tergolong tinggi, ditunjukkan dengan dipenuhinya 8 indikator keterampilan geometri pada ST1, ST2, SS1, dan SR2. Dimana masing-masing subjek memenuhi empat keterampilan geometri keterampilan visual, keterampilan verbal, keterampilan menggambar, dan keterampilan terapan. Masing-masing subjek mampu menyebutkan segiempat berdasarkan gambar dinding rumah adat Osing yang menerapkan konsep kesebangunan yang diberikan, merumuskan definisi segiempat berdasarkan kesebangunan segiempat yang ditunjukkan gambar dinding rumah adat Osing, mengkonstruk segiempat berdasarkan pernyataan kesebangunan dan rangkaian koordinat yang diberikan sedemikian hingga membentuk sebuah pintu rumah adat Osing, 
dan mampu mengembangkan model matematis segiempat melalui gambar atap rumah adat Osing yang berkonsep kesebangunan segiempat.

\section{DAFTAR PUSTAKA}

[1] Abdussakir, A. (2012). Pembelajaran Geometri Sesuai Teori Van Hiele. Madrasah, 2(1).

[2] Ambarwati, R., Sunardi, Yudianto, E., Murtikusuma, R. P. and Safrida, L. N. (2020). Developing Mathematical Reasoning Problems Type Two-tier Multiple Choice For Junior High School Students Based On Ethnomathematics Of Jember Fashion Carnaval, J. Phys. Conf. Ser., 1563(1).

[3] Gustafson, G. and Frisk, P. (1991). Elementary Geometry, 3rd ed. United States of America: Arcata Graphics Company.

[4] Sanjoyo, B. A., Suprapti, S., Asyiah, N. and S. Winda, D. (2008). Matematika Bisnis dan Manajemen untuk SMK Jilid 3. Jakarta: Departemen Pendidikan Nasional.

[5] Alexander, D. and Koberlein, G. (2011). Elementary Geometry for College Students. Canada: Brooks/Cole, Cengage Learning

[6] N. C. of Mathematics. (2000). Principle and Standart for School Mathematics. NCTM: Reston, VA.

[7] Afifah, A. H., Sugiarti, T., and Monalisa, L. A. (2019). Analisis keterampilan geometri siswa kelas x dalam menyelesaikan soal segiempat berdasarkan level van hiele," Kadikma, 10(3), 35-4.

[8] Siregih, S. (2002). Profil Miskonsepsi Siswa SMP tentang Bangun Datar. Forum Pendidik., 23(1), 19-47.

[9] Sofyana, A. U. (2013). Profil Keterampilan Geometri Siswa Smp Dalam Memecahkan Masalah Geometri Berdasarkan Level Perkembangan Van Hiele. MATHEdunesa, 2(1). 